Jurnal Agribis

Vol. 7, No.2, Oktober Tahun 2021

\title{
ANALISIS PENINGKATAN NILAI EKONOMI IKAN LAUT MENJADI OLAHAN NUGET
}

\author{
Herry Nur Faisal ${ }^{1}$ \\ 1,Program Studi Agribisnis, Fakultas Pertanian, Universitas Tulungagung
}

2

E-mail: herrynf81@gmail.com

\begin{abstract}
ABSTRAK
Penelitian ini memiliki tujuan menentukan peningkatan harga produksi ikan laut menjadi nugget olahan sehingga mendapatkan harga yang lebih baik. Kajian dilakukan di kawasan pesisir Pantai Sine, Desa Kalibatur, Kecamatan Kalidawir, Kabupaten Tulungagung. Teknik penelitian menggunakan teknik survei, responden diperoleh dari penggunaan metode purposive sampling bagi para pelaku nelayan pengolahan hasil perikanan. Penambahan biaya olahan yang merupakan hasil akhir dari olahan ikan di Pantai Sine untuk dijadikan nugget agar lebih tahan lama dan menampilkan biaya promosi yang lebih besar. Penghasilan yang diperoleh disesuaikan dari usaha pengolahan hasil perikanan yang terkait dengan unsur teknis dan unsur non teknis. Secara teknis, tingkat ekonomi, jumlah bahan mentah dan jumlah tenaga yang digunakan akan berpengaruh pada jumlah biaya yang dibawa. Sedangkan faktor non teknis yang berpengaruh terhadap besaran pungutan yang dibawa adalah harga masuk dan harga keluaran, dalam hal ini pungutan hasil olahan perikanan.
\end{abstract}

Kata kunci: ikan, nugget, biaya produksi

\begin{abstract}
This study has the aim of determining the increase in the price of marine fish production into processed nuggets so that they get a better price. The study was conducted in the coastal area of Sine Beach, Kalibatur Village, Kalidawir District, Tulungagung Regency. The research technique used survey techniques, respondents were obtained from the use of purposive sampling method for fisherman processing fishery products. The addition of processed costs which are the end result of processed fish at Sine Beach to be used as nuggets to make them more durable and display higher promotional costs. The compensation received is adjusted from the business of processing fishery products related to technical elements and nontechnical elements. Technically, the level of economy, the amount of raw materials and the amount of labor used will affect the amount of costs carried. Meanwhile, non-technical factors that affect the amount of levies carried are the entry price and the output price, in this case the levy on processed fishery products.

Keywords: fish, nuggets, production cost
\end{abstract}

Keywords: fish, nuggets, cost of product 


\section{PENDAHULUAN}

\section{Latar Belakang}

Indonesia mempunyai wilayah perairan yang cukup luas, begitu pula didaerah pesisir selatan Kabupaten Tulungagung. Sehingga dapat diasumsikan bahwa hasil laut yang diperoleh juga cukup banyak, mata pencaharian penduduk didaerah pesisirpun juga sebagai nelayan. Tidak hanya itu, laut juga memberikan arti penting sebagai penopang perekonomian masyarakat daerah pesisir pantai. Salah satu daerah pesisir dipantai Sine juga merupakan salah satu daerah penghasil ikan terbesar di Tulunggaung. Hasil ikan yang ada di daerah tersebut cukup tinggi sehingga banyak dari masyarakat yang memilih profesi nelayan.

Sekarang ini pada kegiatan perikanan serta budidaya ikan tidak lagi hanya dilakukan oleh para kaum lelaki namun juga para wanita. Kelompok wanita di daerah pesisir yang bermula hanya bekerja sebagai ibu rumah tangga, saat ini mulai melakukan produksi ikan dengan mengolah ikan menjadi nugget ataupun olahan ikan lainnya. Hal tersebut dilakukan sebagai upaya membantu perekonomian keluarga. Para wanita daerah tersebut mulai membuat olahan ikan dengan mereka masuk dalam sebuah kelompok pembudidayaan ikan (pokdakan).

Ikan menjadi salah satu hasil perikanan yang cukup banyak dimanfaatkan oleh manusia, namun seiring perkembangan tehnologi dan munculnya kreasi-kreasi baru akan resep makanan sehingga ikan diolah menjadi nuget yang memiliki nilai ekonomis lebih tinggi. Seiring dengan program pemerintah saat ini mengenai GEMARI (Gemar Makan Ikan) sehingga hal tersebut membuat permintaan akan ikan lebih meningkat. Dengan olahan ikan yang semakin berkembang, hal tersebut memberikan dampak positif bagi para nelayan maupun para pelaku pembuat olahan ikan menjadi nugget sehingga lebih memiliki nilai ekonomi yang labih baik.

Cara peningkatan nilai ekonomi dari olahan ikan memberikan mimpi serta harapan besar bagi nelayan dan keluarganya demi mencapai peningkatan kesejahteraan ekonomi keluarga. Namun, seiring berjalannya waktu program tersebut perlu adanya sentuhan dari pemerintah daerah setempat serta mampu memberikan regulasi yang berpihak pada nelayan sehingga mereka memiliki antusias yang tinggi.

Peneliti dalam hal ini melakukan analisis akan perhitungan peningkatan nilai jual ikan melalui olahan nugget supaya hasil dari olahan ikan tersebut semakin memiliki nilai jual lebih dan dapat dikembangkan sebagai usaha peningkatan inovasi mutu hasil perikanan khususnya di kawasan pesisir Pantai Sine, Desa Kalibatur, Kecamatan Kalidawir, Kabupaten Tulungagung 


\section{Tujuan Penelitian}

Mengkaji nilai tambah prooduk-produk olahan perikanan pada industry perikanan tradisional di Kabupaten Tulungagung serta mengkaji implikasi nilai tambah produk olahan perikanan tradisional.

\section{METODE PENELITIAN}

Informasi yang digunakan dalam pertimbangan ini mencakup informasi penting dan informasi tambahan. Informasi penting diperoleh penulis dari hasil wawancara dengan nelayan. Pemahman mengenai system perrdagangan serta persepsi tentang praktik industri penanganan barang perikanan dan varietas dalam jenis komoditas perikanan yang disiapkan dan dipromosikan di daerah yang menjadi lokasi penelitian.

Nelayan yang dijadikan responden dalam kajian ini berjumlah 10 orang, hasil tangkapan nelayan dikumpulkan kemudian dipilah menjadi barang jual langsung dan juga barang jual yang telah dilakukan pengolahan lebih lanjut menjadi nugget ikan.

\section{HASIL DAN PEMBAHASAN}

Penambahan nilai dari sebuah nilai barang akan memberikan kenaikan akan nilai jual sebuah hasil produksi sebuah barang. Sebenarnya tingkat inovasi, jumlah bahan mentah yang digunakan serta banyaknya tenaga kerja yang dipekerjakan akan mempengaruhi jumlah harga yang disertakan. Dari segi non-teknis, dampak jumlah harga yang disertakan adalah pengambilan input dan biaya output, dalam hal ini biaya barang perikanan yang ditangani. Dalam menghitung nilai tambah suatu barang, selanjutnya secara implisit menghitung jumlah keuntungan yang terjadi dalam kegiatan perdagangan penanganan barang perikanan.

Perhitungan nilai tambah hingga harga merupakan penggabungan dari nilai manfaat perusahaan, pemasukan lainnya, dan perhitungan pemberian upah tenaga kerja. Penghargaan yang disertakan itu sendiri terdiri dari manfaat perusahaan dan sumber masukan lainnya. Dengan cara ini keunggulan keseluruhan adalah keseluruhan dari penghargaan yang disertakan dan mengkoordinasikan tunjangan tenaga kerja.

Tindakan perdagangan dari sudut penanganan menjadi suatu hal yang perlu dipahami dan diperhitungkan. Biasanya pada sejumlah masukan yang bersumber dari luar produk perikanan, input yang digunakan dapat berupa fasilitas dan perangkat keras dalam proses produksi barang yang akan dijual. Dari hasil ini dapat dilihat dari nilai masukan lain yang 
didapat diperhitungkan dalam sebuah analisis perhitungan pada pengolahan ikan sehingga memiliki nilai lebih.

Nelayan melakukan pengolahan ikan menjadi nugget dengan harapan memiliki nilai jual yang lebih tinggi. Biaya produksi pada usaha nugget ikan tongkol di bagi menjadi dua, yaitu biaya tetap dan biaya variable. Biaya tetap dihitung dari biaya yang dikeluarkan pelaku usaha yang tidak dipengaruhi oleh besar kecilnya produksi usaha yang diperoleh oleh besar kecilnya jumlah produksi. Contoh dari biaya produksi adalah: penyusutan peralatan (kompor, tabung gas, dandang, ember, gilingan daging, blender), sedangkan contoh biaya variable adalah bahan baku (tepung, ikan tongkol, gas LPG), upah tenaga kerja, pengemasan dan lain-lain. Dari perhitungan yang tengah dilakukan oleh peneliti terdapat perbedaan mengenai harga jual. Pada produk ikan mentah, nelayan dapat menjual ikan tongkol segar

1. Perhitungan kelayakan usaha penulis menggunakan menggunakan analissis Cost Ratio $(\mathrm{R} / \mathrm{C})$ Ratio, dab (B/C) ratio), yaitu:

Ratio antara penerimaan dan biaya (R/C Ratio)

$$
\mathrm{R} / \mathrm{C}=\frac{\text { Total penerimaan }}{\text { Total biaya }}
$$

Dengan kriteria:

$\mathrm{R} / \mathrm{C}>1$, maka usahatani layak untuk diusahakan

$\mathrm{R} / \mathrm{C}=1$, maka usahatani impas

$\mathrm{R} / \mathrm{C}<$, maka usahatani tidak layak untuk diusahakan

Dari hasil perhitungan data primer yang diperolah peneliti, maka dapat dilakukan perhitungan sebagai berikut:

$$
R / C=\frac{R p .78 .425 .000}{R p .42 .662 .639}
$$

$$
=1,83
$$

Apabila dilihat dari perhitungan $B / C$ Ratio tersebut maka nilai dari $R / C$ Ratio sebesar 1,83. Nilai $1,82>1$, sehingga hal tersebut dapat disimpulkan bahwa pengolahan ikan menjadi nugget layak untuk diusahakan.

2. Ratio antara keuntungan dengan biaya ( $\mathrm{B} / \mathrm{C}$ ratio)

$$
\text { B/C Ratio }=\frac{\text { Total pendapatan }}{\text { Total Biaya }}
$$


Dengan kritertia:

$\mathrm{B} / \mathrm{C}>1$, maka usahataninya layak untuk diusahakan

$\mathrm{B} / \mathrm{C}=1$, maka usahataninya impas

$\mathrm{B} / \mathrm{C}<$, maka usahataninya tidak layak untuk diusahakan

Dengan menggunakan data primer yang telah diolah maka nilai $\mathrm{B} / \mathrm{C}$ dari usahatani ini adalah sebesar:

$$
\begin{aligned}
\mathrm{B} / \mathrm{C} & =\frac{\text { Rp. } 35 \cdot 762 \cdot 361,33}{\text { Rp. } 42 \cdot 662,639} \\
& =0.83
\end{aligned}
$$

Dari hasil perhitungan diatas nilai $B / C$ sebesar 0,83 . Nilai $0,83<1$, mengindikasikan secara ekonomi usaha pembuatan nugget ikan tongkol di daerah pesisir Pantai Sine tidak efisien dilakukan.

\section{KESIMPULAN DAN SARAN}

\section{KESIMPULAN}

Berdasar hasil penelitian yang diperoleh, maka dapat diketahui bahwa:

1. Nelayan melakukan pengolahan ikan dengan tujuan memiliki nilai tambah produkproduk pada industri perikanan tradisional di Kabupaten Tulungagung.

2. Nilai tambah dari pengolahan ikan akan memberikan kemanfaatan bagi nelayan sebagai usaha peningkatan perekonomian keluarga masyarakat di daerah pesisir.

\section{S A R A N:}

Saran yang dibsampaikan oleh peneliti adalah sebagai berikut:

1. Adanya pemberian pelatihan kepada nelayan tentang cara mengolah ikan menjadi olahan nugget yang memiliki nilai tinggi.

2. Munculnya peran serta pemerintah daerah setempat untuk memberikan kebijakan akan sebuah kebijakan yang berpihak pada nelayan. 


\section{DAFTAR PUSTAKA}

Andarwulan, N, Kusnandar,F., Herawati, D. 2011. Analisis Pangan. Dian Rakyat. Jakarta.

Badan Standardisasi Nasional. 2006. Standard Nasional Indonesia No. 01-2729.1-2006.

Buckle, K.A., Fleet, R.A., and Wooton, G.H.Food Science. 1987. Hadi, P.Universitas Indonesia. Jakarta

Hadiwiyoto, S. 1993. Tehnologi Hasil Perikanan. Fakultas Teknologi Pertanian UGM. Liberty. Yogyakarta.

Muchtadi, D. 2009. Pengantar ilmu gizi . Bogor : Alfabeta. 1988. Petunjuk Laboratorium IImu Pengetahuan Bahan Pangan. Bogor: Institut Pertanian Bogor.

Ockerrman, H. W. 1983. Chemistry of Meat Tissue. 10 th ed. Animal Science Departement The Ohio State University. The Ohio Agricultural Research and Development Center. Ohio.

Ortoefer FT, Cooper DS. 2004. Initial quality of frying oil. Di dalam: Perkins EG and Erickson MD, Deep Frying Chemistry, Nutrition, and Practical Applications.Champaign: AOCS Press. HIm 29-42.

Rahardi, F., Nazaruddin dan Kristiawati, R, 1995. Agribisnis Perikanan Cetakan 3.Penerbit Swadaya, Jakarta.

Rita, I. 2005. Pembuatan Nugget Ikan Tuna dengan Bahan Pengikat Tepung Tapioka dan Tepung Terigu. [Skripsi] Universitas Andalas. Padang.

Setyaningsih, D. Apriyantono, A., Sari, M.P. 2010. Analisis Sensori untuk Industri Pangan dan Agro. Bogor. IPB Press.

Soeparno. 2005. Ilmu dan Teknologi Daging. Cetakan Ke-4. Gadjah Mada University Press, Yogyakarta.

Tan, S.M. 1994. Processing of Marinated Fish and Battered and Breaded Fish Buger and Nugget, ASEAN-Canada Fisheries Post Harvest Tecnology Project, Phase II.

Tanoto, E. 1994. Pengolahan Fish Nugget dari Ikan Tenggiri (Scomberomorus commersoni). Skripsi Teknologi Pertanian Institut Pertanian Bogor, Bogor. 